\title{
The influence of carbohydrates in the interaction of Paracoccidioides brasiliensis with CCL-6 cells in vitro
}

\author{
Francisco Laurindo da Silva ${ }^{[1]}$, Raphael Sanzio Pimenta ${ }^{[2]}$, Juliana Fonseca Moreira da Silva ${ }^{[2]}$, \\ Déborah Aparecida Negrão Corrêa ${ }^{[3]}$ and Ary Corrêa Junior ${ }^{[4]}$
}

[1]. Laboratório de Microbiologia, Centro de Estudos Superiores de Caxias, Universidade Estadual do Maranhão, Caxias, MA. [2]. Laboratório de Microbiologia Ambiental e Biotecnologia, Universidade Federal do Tocantins, Palmas, TO. [3]. Departamento de Parasitologia, Instituto de Ciências Biológicas, Universidade Federal de Minas Gerais, Belo Horizonte, MG. [4]. Departamento de Microbiologia, Instituto de Ciências Biológicas, Universidade Federal de Minas Gerais, Belo Horizonte, MG.

\begin{abstract}
Introduction: Little is known about the early events in the interaction between Paracoccidioides brasiliensis and its host. To understand the effect of carbohydrates in the interaction between the fungus and epithelial cell in culture, we analyzed the influence of different carbohydrate solutions on the adhesion of $P$. brasiliensis yeast cells to CCL- 6 cells in culture. Methods: Fungal cells were cultivated with the epithelial cell line, and different concentrations of D-fucose, $\mathrm{N}$-acetyl-glucosamine, D-mannose, D-glucosamine, D-galactosamine, sorbitol and fructose were added at the beginning of the experiment. Six hours after the treatment, the cells were fixed and observed by light microscopy. The number of $P$. brasiliensis cells that were adhered to the CCL- 6 monolayer was estimated. Results: The number of adhesion events was diminished following treatments with D-fucose, $\mathrm{N}$-acetyl-glucosamine, D-mannose, D-glucosamine and $\mathrm{D}$-galactosamine as compared to the untreated controls. Sorbitol and fructose-treated cells had the same adhesion behavior as the observed in the control. $P$. brasiliensis propagules were treated with fluorescent lectins. The FITC-labeled lectins WGA and Con-A bound to $P$. brasiliensis yeast cells, while SBA and PNA did not. Conclusions: The perceptual of adhesion between $P$. brasiliensis and CCL- 6 cells decreased with the use of D-mannose, N-acetyl-glucosamine and D-glucosamine. The assay using FITC-labeled lectins suggests the presence of $\mathrm{N}$-acetyl-glucosamine, $\alpha$-mannose and $\alpha$-glucose on the $P$. brasiliensis cell surface. An enhanced knowledge of the mediators of adhesion on P. brasiliensis could be useful in the future for the development of more efficient and less harmful methods for disease treatment and control.
\end{abstract}

Keywords: Paracoccidioidomycosis. Adhesion. CCL-6 cells. Lectin labeling.

\section{INTRODUCTION}

Paracoccidioidomycosis (PCM) is a disease endemic in Latin America that is caused by a thermo-dimorphic fungus, Paracoccidioides brasiliensis ${ }^{1,2}$. The fungi initially infect the lungs, but can also disseminate throughout the entire body ${ }^{3-5}$. Paracoccidioides brasiliensis is a biotrophic pathogen, and an acute and sub-acute clinical form of PCM can be observed in patients ${ }^{3}$. Unfortunately, little is known about the ecological niche of the saprophytic phase of $P$. brasiliensis and its modes of infection and dissemination throughout the host. The cellular events that lead to infection are also unclear, but undoubtedly the disease is established with the conversion of the filamentous phase of the pathogen into its yeast phase, followed by the adhesion of the pathogenic yeast form to the hosts tissue and fungal multiplication ${ }^{5}$.

The adhesion event is better characterized in other pathogenic fungi, and there are only a few reports concerning the precise mechanism of binding between $P$. brasiliensis and its host. Most pathogenic fungi express surface factors that mediate the direct or indirect binding to host cells. For the latter, binding to the host occurs through the interaction with adhesion components, such as extracellular matrix (ECM) proteins, which act as interlinking molecules ${ }^{6,7}$. For a number of pathogens, the ability to bind ECM glycoproteins and the capability of internalization are considered to be

Address to: Dr. Raphael Sanzio Pimenta. Lab. Microbiologia Ambiental e Biotecnologia/UFT. Avenida NS 15, ALCNO 14, 109 Norte s/n, Bloco II/sala 05, 77001-090 Palmas, TO, Brasil. Phone: 5563 3232-8007

e-mail: raphael.pimenta@pq.cnpq.br

Received in 27/03/2012

Accepted in 28/06/2012 important characteristics, and molecules, such as laminin, fibronectin, integrin and carbohydrates, mediate these events ${ }^{6}$.

The diagnostic glycoprotein $\mathrm{gp}_{43}$, which is present on the P. brasiliensis cell wall, has binds to laminin ${ }^{8}$. Other fungi, such as Aspergillus fumigatus, also bind to the laminin molecule9. Another molecule that is associated with the interaction between the fungus and host is fibronectin. The participation of this molecule in the establishment of the host/pathogen interaction is evident in Candida albicans ${ }^{10}$. Laminin and fibronectin normally interact with integrins. In fungi, the presence of integrin-like proteins was characterized in C. albicans and Uromyces appendiculatus ${ }^{10,11}$. The regulation of cell adhesion by fungal surface carbohydrates has been characterized in Fonsecaea pedrosoi and Trichophyton mentagrophytes conidia during the initial stages of interaction with host cells $s^{12,13}$. However, little is known about the mechanism of carbohydrate-mediated adhesion in fungi.

In vitro studies are a helpful in the characterization of adhesion events and mediators. The adhesion $P$. brasiliensis to cultured cells has been previously reported ${ }^{6,14}$. Vero, LLC-MK ${ }_{2}$ and Henle- 407 epithelial cell lines are able to support $P$. brasiliensis adhesion and infection ${ }^{15}$. It has been shown any evidence of the presence of mannose $43 \mathrm{kDa}$ glycoprotein (gp43) of $P$. brasiliensis and also their property of binding to Con $\mathrm{A}^{16}$. To study the role of monosaccharides in the adhesion of $P$. brasiliensis to its host, fungal propagules were cultivated with CCL- 6 cells with and without the presence of sorbitol, D-mannose, D-fucose, N-acetylglucosamine, D-glucosamine, fructose and D-galactosamine solutions. The number of adhesion events was estimated. The lectins wheat germ agglutinin (WGA), Concanavalia eosiformes agglutinin (Con-A), soybeanGlycine max agglutinin (SBA) and peanut-Arachys hypogea agglutinin (PNA) were conjugated to fluorescein isothiocyanate (FITC) and used to detect the presence of carbohydrates on the $P$. brasiliensis surface. 


\section{METHODS}

\section{Microorganism}

The $P$. brasiliensis $\left(\mathrm{Pb}_{18}\right)$ strain was obtained from the Mycology Laboratory Collection in the Biological Sciences Institute at the Federal University of Minas Gerais, Minas Gerais, Brazil (ICB-UFMG) and maintained in its leveduriform state on partially solid Fava-Netto culture medium ${ }^{17}$ at $37^{\circ} \mathrm{C}$. Prior to cellular interactions, the fungi were adapted to Roswell Park Memorial Institute (RPMI)-1640 (Sigma-Aldrich, St. Louis MO-USA) tissue culture medium supplemented with $10 \%$ heat-inactivated fetal bovine serum (Sigma-Aldrich, St. Louis MO-USA) and antibiotic solution (Gentamicin 60mg/L - Ariston - Brazil) under agitation (130rpm) at $37^{\circ} \mathrm{C}$ for 7 days. After incubation, the cell viability was estimated using a FDA/EB (fluorescein diacetate $2.5 \mathrm{mg} / \mathrm{ml}+$ ethidium bromide $20 \mu \mathrm{g} / \mathrm{ml}$ ) solution for $30 \mathrm{~min}$; the green fluorescent cells were considered viable (Olympus BX-41 microscope - WB filter) ${ }^{18}$.

\section{Host cell line}

The host cell line (ATCC CCL-6) was kindly provided by Dr. Judith A. Apletton (Veterinary Medicine School, Cornell University - USA) and maintained in RPMI-1640 (Sigma-Aldrich, St. Louis MO-USA) in 25-ml flasks, supplemented with $10 \%$ heat-inactivated fetal bovine serum (Sigma-Aldrich, St. Louis MO-USA) and antibiotic solution (gentamicin $60 \mathrm{mg} / \mathrm{L}$ - Ariston). The cells were incubated at $37^{\circ} \mathrm{C}$ in an atmosphere containing $5 \% \mathrm{CO}_{2}$. Cell viability was estimated using a $0.4 \%$ Trypan blue solution and the non-stained cells were considered viable. Only cultures with more than $90 \%$ viability were utilized in the infection assays. All experiments were performed with cells obtained from the second passage in RPMI culture medium ${ }^{19}$.

\section{Host/pathogen interaction}

The CCL- 6 cell monolayer was grown on $24 \times 24 \mathrm{~mm}$ sterile cover slips on the bottom of a 6-well culture plate and incubated in RPMI medium as previously reported for $24 \mathrm{~h}$. A fungal inoculum of $100 \mu \mathrm{l}$ of $1 \times 10^{8}$ propagules $/ \mathrm{ml}$ solution was added to the culture plate and incubated for $6 \mathrm{~h}$ at $37^{\circ} \mathrm{C}$ in a $5 \% \mathrm{CO}_{2}$ atmosphere. The test solutions were added to the inoculums. Subsequent to treatment with P. brasiliensis, the cover slips containing the CCL- 6 cell monolayer were washed 3 times in RPMI medium to remove the non-adhered fungal cells and fixed with $4 \%$ paraformaldehyde and $2.5 \%$ glutaraldehyde in $0.1 \mathrm{M}$ phosphate buffer for $2 \mathrm{~h}$. The adhesions events for each treatment were evaluated in triplicate by light microscopy using Nomarsky optics. Fifty randomly chosen microscopic fields were assessed, and the adhesion events were counted. The adhesion inhibition rates were estimated by the following equation: $I R=100-$ [(AdCarb x 100)/AdCont], where: IR = inhibition rate; AdCarb = number of fungal adhered cells on carbohydrates treated cells; and AdCont = number of fungal adhered cells on the control

\section{Adhesion inhibition assay}

The ability of carbohydrates to interfere with the cellular interaction between $P$. brasiliensis and CCL- 6 cell was assessed. The carbohydrates D-mannose, $\mathrm{N}$-acetyl-glucosamine, D-fucose, sorbitol (Calbiochem Co. - San Jose CA, USA) at concentrations of 1, 25, 50 and $75 \mathrm{mM}$, and D-glucosamine and D-galactosamine $(5,10$ and $25 \mathrm{mM})$ or fructose (75mM) (Sigma-Aldrich, St. Louis MO, USA) were added to the fungal inoculums prior to the infections. No carbohydrates were added to the control group.

\section{Immunolocalization}

To better characterize the adhesion of $P$. brasiliensis to host cells, $6 \mathrm{~h}$ post-infection, the cover slips containing the CCL- 6 cell monolayer infected with the fungus were treated with a rabbit extract total antiP. brasiliensis antibody (produced at the Cell Immunology Laboratory at UFMG-Brazil and generously provided by Dr. Goes de Miranda) diluted $1: 100$ in PBS $(0.1 \mathrm{M})$ containing $5 \% \mathrm{BSA}$ for $2 \mathrm{~h}$ at room temperature. Following incubation, the cover slips were treated with rabbit antiIgG monoclonal antibody conjugated to FITC (Sigma-Aldrich, St. Louis MO-USA) diluted 1:20 in PBS containing 5\% BSA for $2 \mathrm{~h}$. The cover slips were examined for fluorescence (Olympus IX70 - BW filter). When necessary, the images obtained from the microscope were acquired using an Optomitrics camera (DMI - 470) and processed using the Image Pro-plus software (Media Cybernetics - London - England).

\section{Labeling of the leveduriform cell with fluorescein-labeled lectin}

Leveduriform cells of $P$. brasiliensis were incubated in presence of FITC-labeled lectins [wheat germ agglutinin (WGA), concanavalin $A$ (ConA) Arachis hypogea (PNA) and Glycine max (SBA) - (EY Laboratories, Inc - California (USA)] diluted in RPMI (sigma) supplemented with $10 \%$ FBS and containing $0.0005 \% \mathrm{Mg}^{2+}$ and $\mathrm{Ca}^{2}$ at concentration of $100 \mu \mathrm{g} / \mathrm{ml}$ for $1 \mathrm{~h}$ at room temperature. The cells were washed three times with RPMI and observed by fluorescence microscopy (Olympus BX-41 - WB filter). When necessary, the microphotographs were recorded using a DMI-470 video camera and the Image Pro-plus software.

\section{Statistical analysis}

The number of cell adhesions per field of the treated and untreated cells were compared using the paired Student's t test with a significance level of $p<0.05$ and converted into a percent of adhesion inhibition. The statistic analysis was performed using BioEstat ver.5.0 (2007).

\section{RESULTS}

\section{Host cell/parasite interaction}

The $P$. brasiliensis cells that adhered to the CCL- 6 monolayer were morphologically different from the non-adhered fungal cells (Figure 1). The non-adherent cells had a traditional shape of a pilot wheel (Figure 1A), and the propagules normally had multiple buds and pseudo-hyphae were rarely observed. However, the adhered cells had an abundant formation of pseudo-hyphae (Figure 1B). These structures were longer than the usual pseudo-hyphae observed on P. brasiliensis cells growing on solid medium. On the host cells, the propagules were firmly attached and were not removed, even during strong agitation. After adhesion, the P. brasiliensis mother cells emitted several expansions that grew on the top of the epithelial cell monolayer. Normally, pseudo-hyphae are observed on the surface of the monolayer, but commonly pseudo-hyphae were observed growing under the surface (Figure 1B; arrows). When the infected monolayer was treated with fluorescent antibodies, the fungal structures located above the surface were fluorescently stained, while the pseudo-hyphae growing under the surface were not (Figure 1C). The monolayer that was not supplemented with carbohydrates had adhesion rates ranging from 75 to 300 events per observation field. 


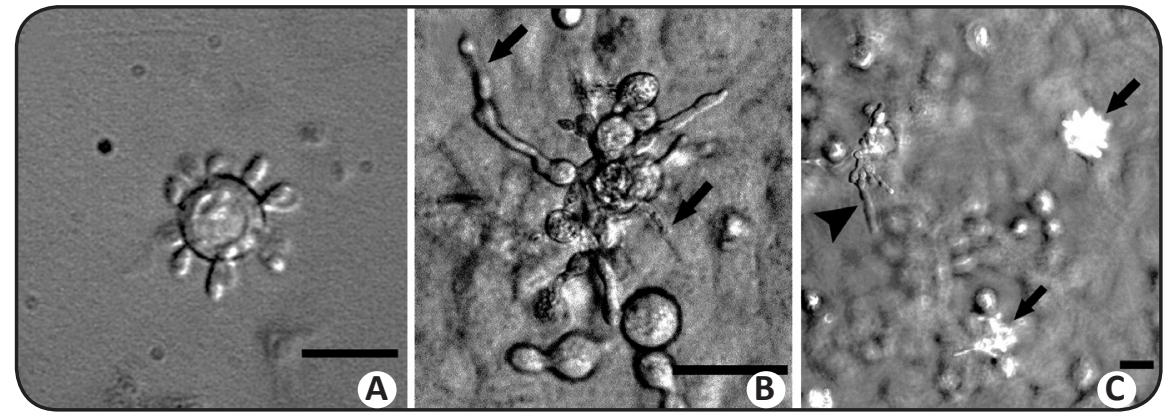

FIGURE 1 - Adhesion and invasion of Paracoccidioides brasiliensis cells on a CCL-6 cell layer. A: Nomarsky microphotograph of non-adhered Paracoccidioides brasiliensis cells in a traditional pilot wheel shape. B: Nomarsky photomicrograph of a Paracoccidioides brasiliensis propagule with intense pseudo-hyphal formation. Some of the pseudo-hyphae are growing underneath the CCL-6 layer (arrow). C: Cell layer treated with fluorescent antiParacoccidioides brasiliensis antibody. Arrowhead depicts fungal pseudo-hyphae growing underneath the cell layer; Arrows indicate fluorescent fungal cells on the top of the monolayer. Bar=10 $\mathrm{mm}$.

\section{Adherence inhibition}

The addition of D-mannose, D-fucose and N-acetyl-glucosamine at concentrations of 25,50 and $75 \mathrm{mM}$ in the interaction medium significantly reduced the adhesion of $P$. brasiliensis to the CCL- 6 cells. The rates of adhesion inhibition in the treatments with D-mannose were reduced to 60,78 and $70 \%$ at concentrations of 25,50 and $75 \mathrm{mM}$, respectively. The decrease in adhesion with the addition of $D$-fucose and $\mathrm{N}$-acetyl-glucosamine was 60,79 and 63 and 58,81 and $82 \%$ at the same concentrations, respectively. Practically no effect was observed after treatment with Sorbitol and Fructose Were observed significative reduction in all concentrations and tested substances $(p<0.05)$ in relation with the control except the to sorbitol at $25 \mathrm{mM}$ (Figure 2). At concentrations of $1 \mathrm{mM}$, no effect was observed, and at concentrations higher than $75 \mathrm{mM}$, the monolayer cell death was higher than $80 \%$. At $12 \mathrm{~h}$ after the addition of carbohydrates, the adhesion rates were not significantly different from the untreated controls. To assess whether the decrease of adhesion inhibition was due to the sequestration or metabolization of soluble carbohydrates, mannose, $\mathrm{N}$-acetylglucosamine and the non-metabolized carbohydrate fructose were freshly added at $8 \mathrm{~h}$ after the initial carbohydrate treatment. Similar levels of adhesion inhibition were observed after the additional carbohydrate treatment as compared with the $4 \mathrm{~h}$ treated cells (Figure 3).

The carbohydrates D-glucosamine and D-galactosamine were added at concentrations of 5,10 and $25 \mathrm{mM}$ because higher

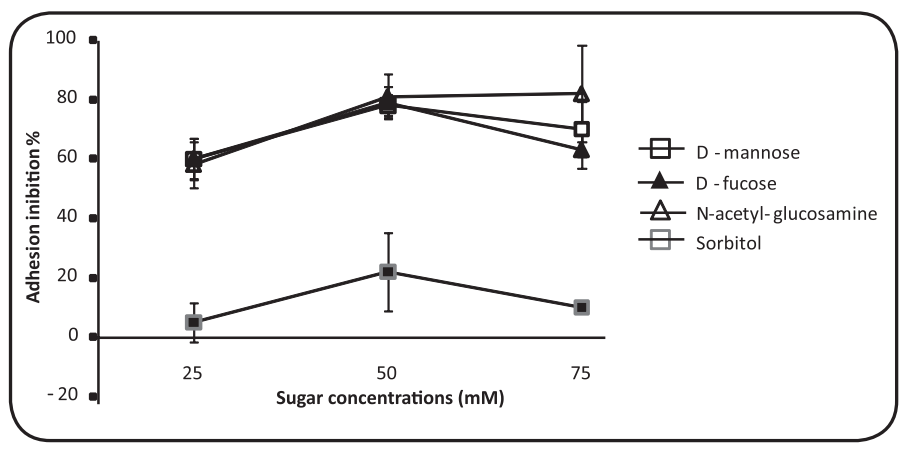

FIGURE 2 - Percentage adhesion inhibition of Paracoccidioides brasiliensis cells to CCL-6 monolayer at $6 \mathrm{~h}$ after treatment with Sorbitol ( $\square$ ), D-mannose ( $\square$ ), D-fucose $(\mathbf{A})$, and $\mathrm{N}$-acetyl-glucosamine $(\triangle)$ at concentrations ranging from 25 to $75 \mathrm{mM}$. concentrations were detrimental to the host cell. The adhesion reductions were estimated at 0,30,37\% for D-glucosamine and 29, 40 and $37 \%$ for D-galactosamine for the corresponding concentrations, respectively. The results were significative only for tests with 5 and $25 \mathrm{mM}$ (Figure 4).

\section{Lectin labeling}

The ConA-FITC and WGA-FITC conjugates effectively labeled $P$. brasiliensis yeast cells (Figure 5). Most importantly, the labeled cells did not fluoresce if treated with $100 \mathrm{mM}$ of D-mannose (ConA-FITC pretreated propagules) and N-acetyl-glucosamine (WGA-FITC pre-treated propagules) (data not shown). We were unable to detect PNA-FITC and SBA-FITC labeling, even after enhancing the camera detection by frame averaging and increasing the camera sensitivity. The adhered $P$. brasiliensis cells were also labeled with the ConA-FITC and WGA-FITC conjugates (Figures 5A and 5B). A small amount of fluorescence the CCL-6 mammalian cell was also observed (Figure $5 \mathrm{C}$ ).

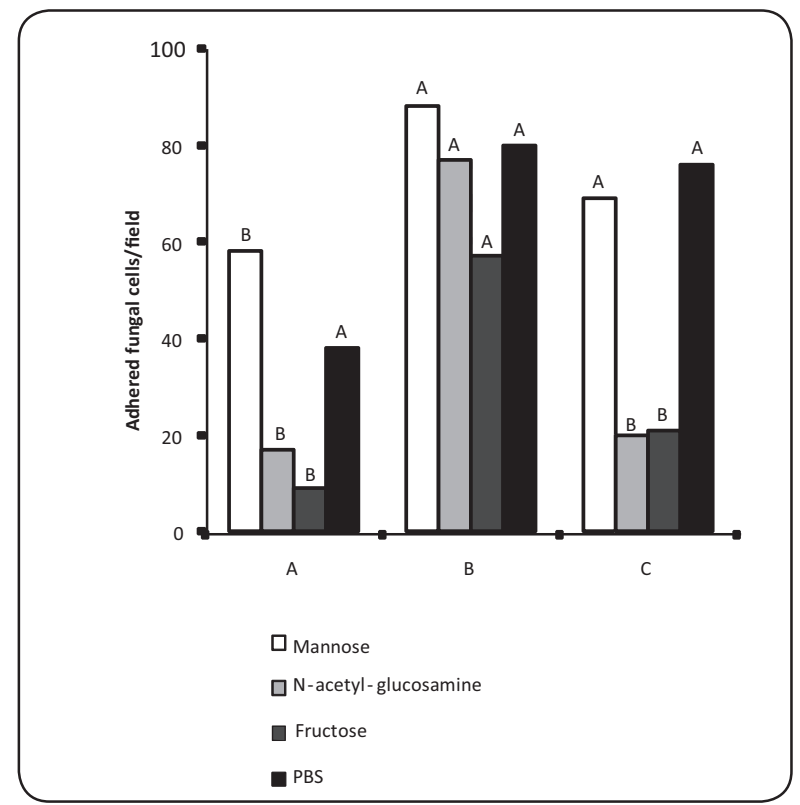

FIGURE 3 - Number of Paracoccidioides brasiliensis cells adhered to a CCL-6 monolayer after treatment with $75 \mathrm{mM}$ mannose $(\square), \mathrm{N}$ - acetyl-glucosamine $(\square)$, fructose $(\square)$ or PBS buffer $(\square)$ after 4 (A), and 12 (B)h of sugar addition or after a second addition of the sugar $8 \mathrm{~h}$ after incubation (C). 


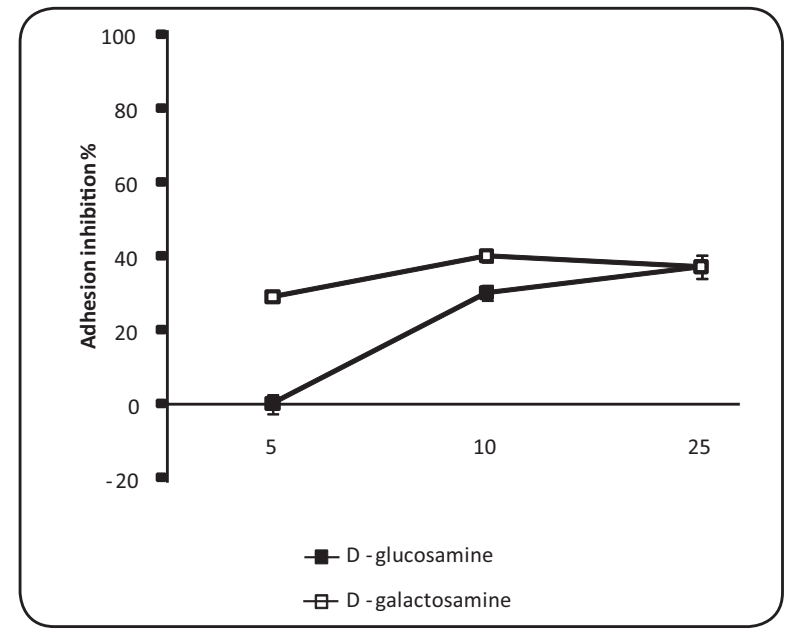

FIGURE 4 - Percentage of adhesion inhibition of Paracoccidioides brasiliensis to the CCL-6 monolayer at $6 \mathrm{~h}$ after treatment with D-glucosamine ( $\square)$ and D-galactosamine $(\square)$ at concentrations ranging from 5 to $25 \mathrm{mM}$.
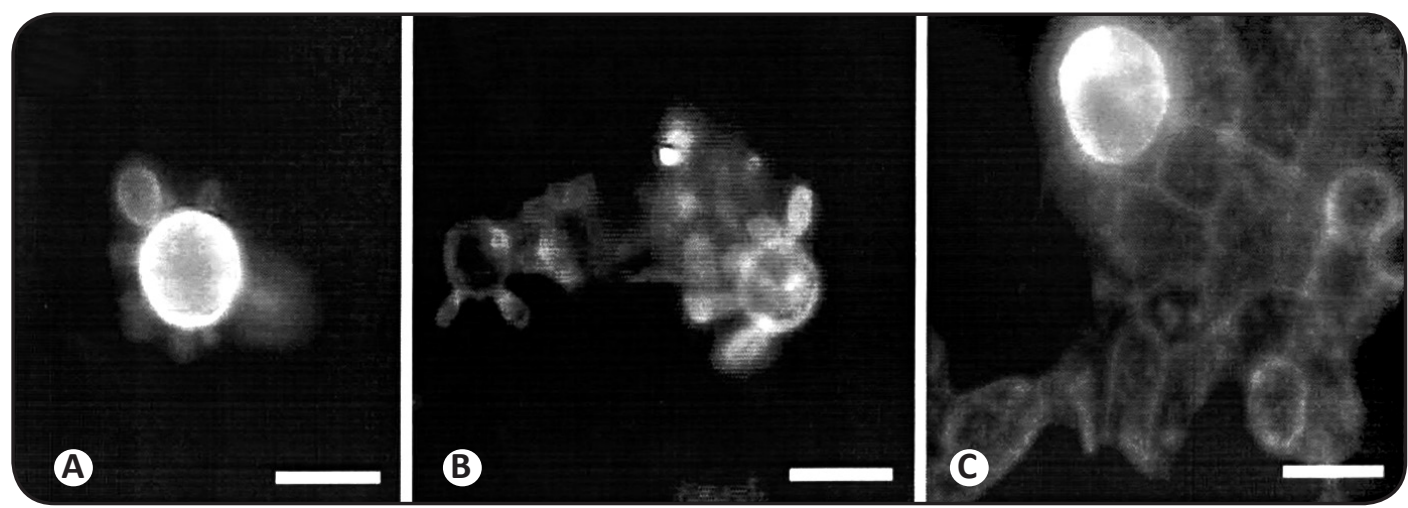

FIGURE 5 - Paracoccidioides brasiliensis cells after treatment with fluorescent lectins. A: Pilot wheel Paracoccidioides brasiliensis cells stained by WGA-FITC conjugate. Note the intense fluorescence of the mother cell. B: Fungal cells labeled by ConA-FITC conjugate. The cells were evenly labeled. C: Paracoccidioides brasiliensis cell adhered to CCL- 6 cells after treatment with the WGA-FITC conjugate. Note the intense labeling of the fungal cell and the weak signal in the CCL- 6 cell.

WGA: wheat germ agglutinin; Con-A: Concanavalia eosiformes agglutinin; FITC: fluorescein isothiocyanate.

\section{DISCUSSION}

Most of our knowledge concerning the interaction between Paracoccidioides brasiliensis and its host cell is derived from studies using in vitro cell culture models ${ }^{6,7,14}$. However, although insightful, these reports did not assess the role of particular components in the infection. Little is known about adhesion mediators produced by $P$. brasiliensis during the course of the infection. The $\mathrm{gp}_{43^{\prime}}$ is the only candidate molecule presumed to play a role in the regulation of the fungal propagule to its host ${ }^{8}$. The effect of $\mathrm{gp}_{43}$ in adhesion has been inferred from indirect evidence due to the difficulty of providing direct proof. It has been previously shown that the purified glycoprotein is able to bind to laminin in vitro, and P. brasiliensis cells pre-treated with laminin bind more effectively to Madin-Darby canine kidney cells. Furthermore, when $P$. brasiliensis laminin-treated cells were injected into guinea pigs, a higher number of granuloma was formed in the host in comparison with the guinea pig injected with the untreated fungal cells ${ }^{8}$. Although the adhesion function of $\mathrm{gp}_{43}$ adhesion function was not directly tested. The gp43 is rich in mannose and mannose interfered in the adhesion of $P$. brasiliensis to CCL- 6 cell. The addition of monosaccharide D-mannose to the interaction medium prior to infection significantly reduces the adhesion of $P$. brasiliensis to CCL- 6 cells. The adhesion reduction was more significant at a concentration of $50 \mathrm{mM}$, reaching $79 \%$ inhibition (Figure 2). The participation of mannose residues in the interaction mechanism between the host and pathogen was also observed in other infection models ${ }^{12,20}$.

Here, we report that some carbohydrates were able to diminish adhesion in vitro at rates as high as $90 \%$ and therefore, it's the role of these carbohydrates in the natural adhesion process has to be investigated. The role of carbohydrates in modulating fungus/host cell adhesion has been reported previously ${ }^{9,21}$.

The addition of monosaccharide D-mannose to the interaction medium prior to infection significantly reduces the adhesion of P. brasiliensis to CCL- 6 cells. The adhesion reduction was more 
significant at a concentration of $50 \mathrm{mM}$, reaching $79 \%$ inhibition (Figure 2). The participation of mannose residues in the interaction mechanism between the host and pathogen was also observed in other infection models $s^{13,20}$. Most of the work, however, was conducted using manopyranosides, lectins or glycosylated substrates as adhesion inhibitors. Normally, sugars linked to carrier protein are used to prevent the carbohydrate from being metabolized or sequestered by the cells during the assay. In our case the sugar itself has an effect on adhesion. Interestingly, if the co-cultivation was performed for a longer time, the adhesion inhibition would decrease but could be restored by the addition of mannose to the cultivation media. The restoration is probably due to the fact that the cell effectively processes mannose over time and therefore, its concentration decreases in the incubation medium, resulting in the decrease of its effect on inhibition of adhesion. An increase in mannose concentration restores the inhibition. Similar results were observed with $\mathrm{N}$-acetyl-glucosamine (Figure 3). Fructose is a sugar that is not metabolized by either the fungal or the host cells and did not have an effect on adhesion.

Another competitor of adhesion utilized in our studies was D-fucose. Fucose is a deoxyhexose that is present in a wide variety of organisms. In mammals, fucose-containing glycans have important roles in blood transfusion reactions, selectin-mediated leukocyteendothelial adhesion, host-microbe interactions, and numerous ontogenic events, including signaling by the Notch receptor protein family ${ }^{21}$. The involvement of fucose in the interaction between fungi and its host was established by the characterization of the fucose receptor in the germination tubes of $\mathrm{C}$. albicans ${ }^{22}$.

The addition of $\mathrm{N}$-acetyl-glucosamine to the interaction medium significantly decreases the adhesion percentage of the fungi to the cellular host type. The adhesion reduction was more significant at concentrations of 50 and $75 \mathrm{mM}$ (Figure 2). Results similar for Fonsecaea pedrosoi pre-incubated with the $\mathrm{N}$-acetyl-glucosamineBSA conjugate ${ }^{13}$.

D-glucosamine and D-galactosamine were also able to decrease the adhesion index of $P$. brasiliensis to CCL-6 cells (Figure 4). Those sugars have been implicated in the adhesion of Entamoeba histolytica to epithelial cells and C. albicans to lymphocytes ${ }^{10,23}$.

Carbohydrates have been described as important adhesion mediators in many biological models, and this idea remains consistent with regard to the interaction of $P$. brasiliensis and epithelial CCL-6 cells. The cell treatment with those carbohydrates actually decreases the adhesion efficiency of the fungal cells. Unfortunately, even though and inhibitory effect was observed, we were not able to directly implicate the carbohydrates in the physiological event of adhesion. Several other molecules could also play a role in the process and would be not detected by our experimental approach.

Therefore, further studies are necessary to identify and characterize the molecules with affinity for carbohydrates that are present on the fungal surface and/or its host. Lectins are described as proteins that able to bind particular sugars. In several other biological systems, lectins are believed to be the cellular receptor for carbohydrates that modulate adhesion and cell recognition, for example. To assess whether the lectins are capable of recognizing carbohydrates on the surface of $P$. brasiliensis, we labeled yeast cells with ConA, WGA, PNA and SBA lectins conjugated to FITC. Of the four lectins assessed, only ConA and WGA labeled P. brasiliensis cells.
The Con-A lectin specifically recognized $\alpha$-mannose and $\alpha$-glucose, while WGA bound to $\mathrm{N}$-acetyl-glucosamine. These sugars were also able to inhibit $P$. brasiliensis adhesion to CCL- 6 cells; therefore, one might suggest that those sugars are present on the $P$. brasiliensis surface and are the receptors responsible for cell-to-cell adhesion. However, PNA, which binds terminal galactose, and SBA, which recognizes $\mathrm{N}$-acetylgalactosamine and galactose, were not able to detect these sugars on the surface of $P$. brasiliensis cells. Inhibitory assays with $\mathrm{N}$-acetylgalactosamine showed a strong decrease of adhesion therefore, one would expect that the SBA lectin would recognize such a sugar on $P$. brasiliensis cells. One possible argument for the apparent contradiction in the data is that the sugar would be present on the host cell surface.

However, SBA-FITC was also unable to show binding sites on the CCL6 cells (data not shown). The role of galactosamine is therefore unclear. Adhesion is as early event in most of the pathogen/host interactions and is crucial for efficient disease development. Several mediators are constantly being implicated as having a role in the adhesion event, but a definitive experiment is yet to be proposed. Our results, are circumstantial, and only emphasize the effect of $P$. brasiliensis surface carbohydrates in the adhesion/recognition process. An enhanced knowledge of the mediators of adhesion on the biotrophical fungus P. brasiliensis will be useful in the future for the development of more efficient and less harmful methods for disease treatment and control.

\section{CONFLICT OF INTEREST}

The authors declare that there is no conflict of interest.

\section{FINANCIAL SUPPORT}

This work was supported financial by the Conselho Nacional de Desenvolvimento Científico e Tecnológico (CNPq).

\section{ABSTRACT IN PORTUGUESE}

\section{A influência de carboidratos na interação entre Paracoccidioides brasiliensis e células CCL-6 (in vitro)}

Introdução: Pouco se conhece a respeito dos eventos iniciais que mediam as interações entre Paracoccidioides brasiliensis e seus hospedeiros. Com a intenção de compreender a importância de carboidratos junto a estas interações, foram analisados os efeitos de soluções de carboidratos sobre a adesão de células leveduriformes de $P$. brasiliensis sobre culturas de células CCL-6. Métodos: As células fúngicas foram cultivadas com as células epiteliais e diferentes concentrações de D-fucose, N-acetyl-glucosamina, D-manose, D-glicosamina, D-galactosamina, sorbitol e frutose foram adicionadas ao cultivo no início da interação. Após $6 \mathrm{~h}$ de tratamento, as células foram fixadas e observadas em microscópio óptico. Resultados: Os tratamentos utilizando D-fucose, N-acetilglicosamina, D-manose, D-glicosamina e D-galactosamina reduziram os números de adesões quando comparados com o controle. Os tratamentos realizados com o uso de sorbitol e frutose apresentaram os mesmos resultados observados no controle. Para detectar a presença de carboidratos na superfície do fungo, propágulos de $P$. brasiliensis foram tratados com lectinas fluorescentes. WGAFITC e Con-A-FITC se ligaram às células de $P$. brasiliensis ao contrário de SBA e PNA. Conclusões: $O$ percentual de adesão entre $P$. brasiliensis e células CCL- 6 foi reduzido com o uso de $\mathrm{D}$-manose, $\mathrm{N}$-acetil-glicosamina e $\mathrm{D}$-glicosamina. $\mathrm{O}$ uso de lectinas marcadas sugeriu a presença de $\mathrm{N}$-acetil-glicosamina, $\alpha$-manose e $\alpha$-glicose na superfície de $P$. brasiliensis. Estes resultados contribuem para o aumento do conhecimento relacionado aos mediadores de adesão de $P$. brasiliensis, e poderão ser utilizados no futuro para o desenvolvimento de medidas mais eficientes para o controle e tratamento deste patógeno.

Palavras-chaves: Paracoccidioidomicose. Adesão. Células CCL-6. Lectina fluorescente. 


\section{REFERENCES}

1. Montenegro MR, Miyaji M, Franco M, Nishimura K, Coelho KI, Horie Y, et al. Isolation of fungi from nature in the region of Botucatu state of São Paulo, Brazil, an endemic area of paraococcidioidomycosis. Mem Inst Osvaldo Cruz 1996; 91:665-670.

2. Loth EA, Castro SV, Silva JR, Gandra RF. Occurrence of 102 cases of paracoccidioidomycosis in 18 months in the Itaipu Lake region, western Paraná. Rev Soc Bras Med Trop 2011; 44:636-637.

3. Borges-Walmsley MI, Chen D, Shu X, Walmsley AR. The pathobiology of Paracoccidioides brasiliensis. Trends Microbiol 2002; 10:80-87.

4. Brummer E, Castaneda E, Restrepo A. Paracoccidioidomycosis: an update. Clin Microbiol 1993; 3:89-113.

5. Franco M. Host-parasite relationships in paracoccidioidomycosis. J Med Vet Mycol 1986; 25: 5-18.

6. Mendes-Giannini MJS, Ricci LC, Vemura M, Toscano E, Arnus CW. Infection and apparent invasion of Vero cells by Paracoccidioides brasiliensis. J Med Vet Mycol 1994; 32:189-195.

7. Sahai AS, Manocha MS. Chitinase of fungi and plants: their involvement in morphogenesis and host-parasite interactions. FEMS Microbiol 1993; 11:317-338.

8. Vicentini AP, Gesztesi JL, Franco MF, Sousa W, Moraes J, Travassos LR, et al. Binding of Paracoccidioides brasiliensis to laminin through surface glycoprotein gp-43 leads to enhancement of fungal pathogenesis. Infect Immun 1994; 62:1465-1469.

9. Trochin G, Esnault K, Renier G, Filmon R, Chabasse D, Bouchara JP. Expression and identification of a laminin-binding protein in Aspergillus fumigatus. Infect Immun 1997; 65:9-15.

10. Forsyth CB, Mathews HL. Lymphocyte adhesion to Candida albicans. Infect Immun 2002; 70:517-527.

11. Corrêa AJ, Staples RC, Hoch HC. Inhibition of thigmostimulated cell differentiation with RGD-peptides in Uromyces germlings. Protoplasma 1996; 194:91-102.
12. Esquenazi D, Souza W, Alviano CS, Rozental S. The role of surface carbohydrates on the interaction of microconidia of Trichophyton mentagrophytes with epithelial cells. FEMS Immunol Med Microbiol 2003; 35:113-123.

13. Limongi CL, Rozental S, Alviano CS, Souza W. The influence of surface carbohydrates on the interaction of Fonsecaea pedrosoi with Chinese hamster ovary glycosylation mutant cell. Mycopathol 1997; 138:127-135.

14. Hanna SA, Juliana LMS, Mendes-Giannini MJ. Adherence and intracellular parasitism of Paracoccidioides brasiliensis in Vero cells. Microbes Infec 2000; 2:877-884.

15. Mendes-Giannini MJS, Taylor ML, Bouchara JB, Bugers E, Calich VLG, Escalante ED, et al. Pathogenesis II. Fungal responses to host responses: interaction of host cells with fungi. Med Mycol 2000; 1:113-123.

16. Franco M, Lacaz CS, Restrepo-Moreno A, Del Negro G. Paracoccidioidomycosis. Boca Raton: CRC Press; 1994

17. Fava Neto C. Contribuição para o estudo imunológico da blastomicose de Lutz. Rev Inst Adolpho Lutz 1961; 21:99-194.

18. Calich VLG, Purchio A, Paula CR. A new fluorescent viability test for fungi cells. Mycopathol 1978; 66:175-177.

19. Silva FL. Estabelecimento in vitro de modelo para o estudo do processo infectivo de Paracoccidioides brasiliensis em células hospedeiras de mamíferos. [Dissertation]. [Belo Horizonte]: Universidade Federal de Minas Gerais; 2001; 104p.

20. Vardar-Üunlu G, McSharry C, Douglas LJ. Fucose-specific adhesins on germ tubes of Candida albicans. FEMS Immunol Med Microbiol 1998; 20:55-67.

21. Agnani G, Tricot-Doleux S, Houalet S, Bonnaure-Mallet M. Epithelial cell surface sites involved in the polyvalent adherence of Porphyromonas gingivalis: a convincing role for neuraminic acid and glucuronic acid. Infection Imm 2003; 71:991-996.

22. Becker DJ, Lower JB. Fucose: biosynthesis and biological function in mammals. Glycobiol 2003; 13:41-53.

23. Espinosa-Cantellano M, Martinez-Palomo A. Pathogenesis of intestinal amebiasis: From molecules to disease. Clin Microbiol 2000; 13:318-331. 